\title{
ASSESSMENT OF THE EFFICIENCY OF DISINFECTION METHODS FOR IMPROVING WATER QUALITY
}

\author{
A. O. Sojobi ${ }^{1,}$, S. I. Dahunsi ${ }^{2}$ and A. O. Afolayan ${ }^{3}$ \\ 1, 3 Department of Civil EngineEring, LANDMARK University, PMB 1001, OMU ARAN, KWARA StATE, NIGERIA \\ 2 DEPARTMENT OF Biological SCIENCES, LANDMARK UnivERSity, PMB 1001, OMU ARAN, KWARA STATE, NIGERIA \\ E-mail addresses1adebayosojobi@gmail.com,2dahunsi.olatunde@Imu.edu.ng,3 olafolayan56@gmail.com
}

\begin{abstract}
The efficiencies of three disinfection methods namely boiling, water guard and pur purifier were assessed. The micro-organisms isolated from the groundwater samples were Escherichia coli and E. aerogenes. The major components of Water Guard and Pur Purifier were found to be $\mathrm{NaNO}_{2}, \mathrm{SO}_{4}, \mathrm{Cl}_{2}$, and $\mathrm{NaNO}_{2}, \mathrm{Ca}, \mathrm{CaCO}_{3}, \mathrm{SO}_{4}, \mathrm{Mg}$ and $\mathrm{ClO}_{2}$ respectively. Pur purifier was most effective for removal of electrical conductivity, nitrate, total coliform and yeast while Water Guard was most effective for removal of phosphate, potassium, E-Coli and Fungi. In addition, boiling and water guard were most effective for removal of turbidity while boiling was most effective for removal of chlorine. Furthermore, Water Guard was found to be the cheapest with an estimated monthly household cost of A240. Use of Water Guard for disinfecting household groundwater sources utilized for drinking and cooking is highly encouraged among the rural populace to safeguard their health against waterborne diseases.
\end{abstract}

Keywords. boiling, disinfection, efficiency, pur purifier, water guard

\section{INTRODUCTION}

Provision of safe and portable drinking water is one of the most important health-related water infrastructural programs in the world [1]. Water is an indispensable resource for supporting life systems [2$4]$, while access to safe drinking water is a basic human right, which is essential for healthy life [5-7]. Globally, about 1.1 billion people lack access to improved water supplies [8]. The enormous consequences of these apparent infrastructural deficits result in an estimated 4 billion cases of diarrhea where more than 5 million deaths occur annually $[8,9]$. Furthermore, the acute shortage of potable freshwater is aggravated by lack of proper management, industrial development, population growth, increased pollution, corruption and poor implementation of water-related infrastructural projects, which continue to put a heavy strain on the provision of adequate water resources in terms of distribution, availability, access and quality [10-11].

This critical shortage need to be addressed especially in developing countries [12-13] where extreme poverty increases exposure to waterborne diseases like cholera, typhoid, shigellosis, diarrhea, etc [14-15]. [16] Reported that 66 million people in Nigeria do not have good drinking water source, a situation which has led to the proliferation and consumption of different contaminated water sources [17] with attendant health burden.

Intervention efforts to combat water-related diseases are categorized into four namely improved hygiene practices, improved sanitation, improved access to water and improved water quality [18]. Point-of-use water treatment commonly used at household level makes use of physical, biological or chemical means [19] or their combinations to disinfect water that might have been contaminated or re-contaminated during collection, transport or storage [20], in order to improve water quality. The varieties of the treatment methods include boiling, pur purifier, water guard sand filter, ceramic filter, microfiltration, anion exchange, reverse osmosis, Aquatab, Aqua Guard and Zero-B Purifier [21-13].

Boiling is the oldest and most common water treatment method in developing world and among the vulnerable, poor population [24-26]. According to [27], chlorination is also widely practiced at community level and the various sources include sodium hypochlorite. Water guard use is limited mostly to urban areas and is often unavailable in most 
rural areas in Nigeria largely due to difficulty in reaching rural areas owing to bad roads and weak advertisement of the product [28]. Pur purifier, developed by Procter and Gamble Pakistan under the trademark of Procter and Gamble Company in conjunction with Centers for Disease Control and Prevention, is also used. The product contains powdered ferric sulphate, a flocculant and calcium hypochlorite, [Ca $\left.(\mathrm{OCl})_{2}\right]$, which is a disinfectant [27]. The ferric sulphate removes suspended particles through settling from water.

The objective of this laboratory study therefore is to investigate the efficiency of three of the various drinking water treatment methods commonly used in developing countries with particular reference to $\mathrm{Omu}$ Aran in Kwara State of Nigeria namely boiling, water guard and Pur Purifier.

\section{METHODOLOGY}

\subsection{Description of Study Area}

Irepodun Local Government Area (LGA) is one of the sixteen LGAs in Kwara State, located in the North Central geopolitical zone in Nigeria. The annual rainfall and temperature in Kwara State ranges from $1234.9 \mathrm{~mm}-1468.5 \mathrm{~mm}$ and $32.3-36.4^{\circ} \mathrm{C}$ respectively, while the annual mean relative humidity ranges from 47.6-52.4. Basic amenities such as piped-borne water and hospitals are grossly inadequate. Based on statistics by the National Bureau of Statistics (NBS), $88.68 \%$ of the population in Kwara State is poor, which is one of the highest in Nigeria and indicates extreme level of poverty [29].

[30] Reported that $68.7 \%$ and $20.2 \%$ of the Ilorin populace use well water and borehole as drinking water sources. Furthermore, $41.2 \%$ of the households in Irepodun LGA rely on borehole while $31.2 \%$ rely on wells as their major sources of water for drinking and cooking [31]. Hence, this information informed our focus on these two major sources of water by the rural households in the LGA. [32] sampled 4,061 children under five years of age in nine rural communities in Southwest of Irepodun LGA and reported that 21.6\% of the children had diarrhea.

\subsection{Sampling Communities}

The rural communities sampled were Omu Aran, Oro, Edidi and Oke Onigbin within Irepodun Local Government of Kwara State. The predominant sources of water supply for drinking, cooking and other domestic purposes are borehole and shallow wells besides sachet water due to the irregularity in the supply of public water.

\subsection{Water Sampling and Treatment}

Water samples for this study were collected between April to November, 2014 from boreholes and shallow wells. Samples were collected with the aid of new high-density PET screw-capped containers of $1.5 \mathrm{~L}$ capacity. Water from the boreholes was allowed to run for 5 minutes, immediately followed by reduction in the water flow in order to avoid splashing during filling of bottles. Gasses were removed from the bottles by filling and emptying the bottles before the collection of actual water samples. For shallow wells, the water was given a little disturbance with a drawing bucket for about five consecutive times to allow for proper mixing of the well water before the actual samples were drawn out. In each case, the PET bottles and stoppers were thoroughly washed with distilled water thrice and once with the water to be sampled before the actual sample collection [7].

At each site, three bottles were filled with water, one each for boiling, water guard and Pur Purifier treatments having no added acid while the fourth bottle was filled with the water from the same point and acidified by adding a few drops of $5 \% \mathrm{HNO}_{3}$ to stop microbial proliferation. At the same time, samples for microbial analysis were collected using autoclave-sterilized sample bottles from the same locations [7]. The water samples were preserved in a refrigerator at $4{ }^{\circ} \mathrm{C}$ to keep the water content intact until treatment and analyses were carried out. A total of 48 raw water samples per town were collected making a total of 192 water samples in general for the baseline and were subjected to treatments such as boiling, pur purifier and water guard. The various water treatments were applied in the Chemical Engineering Laboratory, Landmark University within thirty minutes of sample collection.

For boiling purposes, a steel cooking pot was thoroughly washed thrice to remove any form of external contamination and filled with the water sample and covered appropriately. Boiling was done with the aid of Mikachi electric stove for twelve minutes to achieve rolling boiling after surface boiling was observed after seven minutes of boiling. The surface boiling temperature ranges between $78^{\circ} \mathrm{C}$ $85^{\circ} \mathrm{C}$. The covered pot with water was removed from the electric stove after achieving rolling boiling for five minutes during which the rolling boiling temperature 
averages $100^{\circ} \mathrm{C}$ and was allowed to cool for ten minutes before samples were taken for analyses.

The Water Guard used was manufactured by Tuyil Pharmaceutical Industries limited, Ilorin, Nigeria but sold as Water Care. Water sample was poured into a clean measuring glass cylinder to ascertain its volume. The standard recommended dosage was to pour one capful of water guard into 25 litres of jerry can of water. Based on the volume obtained, the corresponding volume of water guard was weighed out on a measuring balance and added to the cylinder and thoroughly mixed for two minutes and shaken. The WG-treated water was allowed to stand for thirty minutes before samples were taken for analyses.

The Pur Purifier (Pur) of water used for water treatment was produced by Procter and Gamble, Pakistan under the trademark of Procter and Gamble Company. The collected water sample was poured into a clean, glass measuring cylinder to ascertain its volume. The recommended dosage was to treat 10 litres of water with one packet of Pur Purifier. After ascertaining the volume of water sample, corresponding amount of Pur Purifier weighed out on a balance, was added and stirred thoroughly with a clean glass rod for five minutes. The solution was allowed to stand for five minutes when flocculant separation was observed. The solution was filtered with a new, clean $100 \%$ filter cotton cloth without holes into a clean glass measuring cylinder, from where samples were taken for analyses. All the water samples including the baseline and treated water samples were transported within three hours to Central Research Laboratory of Federal University of Akure, Ondo State, Nigeria for physical, chemical and microbiological analyses.

Chemical composition of the WG and PP was determined using Paqualab Photometer with model number PT741E1113039 in the Environmental Laboratory of Department of Civil Engineering, Landmark University. In order to determine their chemical composition, $1 \mathrm{mg}$ of both WG and Pur Purifier were made up to $10 \mathrm{mg}$ of deionized water in a graduated test tube which was compared to a blank control.

\subsection{Analytical Procedure}

Physical parameters including pH (HI 9024-C, Hanna Instruments, Smithfield, RI, USA), temperature (HI 98517, Hanna Instr.), salinity (HI 19311, Hanna Instr.), electrical conductivity (HI 2315, Hanna Instr.), and total dissolved solids (TDS) (VSI 22, VSI Electronics Private Limited, Punjab, India) were analyzed in-situ using the afore-mentioned hand digital meters. Dissolved oxygen was analyzed using the azide modification of Winkler's method [33]. Chloride content was determined by titration according to the method described in [33]. Determination of the major anions was carried out with Ultraviolet spectrophotometer screening method [33] with a UV spectrophotometer (DR 2800, HACH, Washington, USA) [6-7; 15]. To maintain reliability and reproducibility in the analyses, the blank, standard, and pre-analyzed samples were analyzed after every 10 samples [7]. Standard methods were used to determine the total viable and coliform bacteria counts as colony forming units (CFU) in water samples [34]. Metals analysis were done with the aid of atomic absorption spectrophotometer (AAS) (Sens AA 3000, GBC, Australia) using the method in [34]. For each water parameter, the average values obtained in the baseline for boreholes and wells water samples termed pre-treatment water samples were compared with the average of the post-treated water samples.

Table 1: Statistics of Physico-chemical analyses of Baseline ground water for the study area

\begin{tabular}{ccccccc}
\multicolumn{6}{c}{ Baseline ground water for the study area } \\
\hline \multirow{2}{*}{ Parameters } & $\begin{array}{c}\text { No. } \\
\text { Data }\end{array}$ & \multirow{2}{*}{ Max } & Min & \multirow{2}{*}{ Avg } & SD & SON35 \\
\hline Turb (NTU) & 192 & 0.06 & 0.00 & 0.03 & 0.02 & 5 \\
$\mathrm{EC}(\mathrm{ms} / \mathrm{cm})$ & 192 & 8.01 & 0.79 & 4.15 & 1.15 & 1000 \\
$\mathrm{pH}$ & 192 & 8.07 & 3.16 & 5.64 & 0.94 & $6.5-8.5$ \\
$\mathrm{TS}(\mathrm{mg} / \mathrm{l})$ & 192 & 0.67 & 0.05 & 0.30 & 0.05 & - \\
$\mathrm{TDS}(\mathrm{mg} / \mathrm{l})$ & 192 & 2.53 & 0.19 & 0.40 & 0.39 & 500 \\
$\mathrm{TH}(\mathrm{mg} / \mathrm{l})$ & 192 & 219.51 & 91.99 & 154.4 & 6.43 & - \\
$\mathrm{DO}(\mathrm{mg} / \mathrm{l})$ & 192 & 11.01 & 4.49 & 7.25 & 1.06 & $7.5(\mathrm{FEPA})^{36}$ \\
$\mathrm{Cl}(\mathrm{mg} / \mathrm{l})$ & 192 & 46.85 & 4.48 & 24.63 & 3.3 & 250 \\
$\mathrm{NO}(\mathrm{mg} / \mathrm{l})$ & 192 & 192.25 & 3.18 & 50.12 & 5.14 & 50 \\
$\mathrm{SO}(\mathrm{mg} / \mathrm{l})$ & 192 & 7.2 & 4.49 & 5.41 & 0.37 & 100 \\
$\mathrm{PO}(\mathrm{mg} / \mathrm{l})$ & 192 & 20.23 & 11.4 & 15.80 & 2.92 & - \\
$\mathrm{Cd}(\mathrm{mg} / \mathrm{l})$ & 192 & $\mathrm{ND}$ & $\mathrm{ND}$ & $\mathrm{ND}$ & $\mathrm{ND}$ & 0.003 \\
$\mathrm{~Pb}(\mathrm{mg} / \mathrm{l})$ & 192 & 0.05 & 0.02 & 0.04 & 0.01 & 0.01 \\
$\mathrm{Cr}(\mathrm{mg} / \mathrm{l})$ & 192 & $\mathrm{ND}$ & $\mathrm{ND}$ & $\mathrm{ND}$ & $\mathrm{ND}$ & 0.05 \\
$\mathrm{Ni}(\mathrm{mg} / \mathrm{l})$ & 192 & $\mathrm{ND}$ & $\mathrm{ND}$ & $\mathrm{ND}$ & $\mathrm{ND}$ & 0.02 \\
$\mathrm{Zn}(\mathrm{mg} / \mathrm{l})$ & 192 & 0.04 & 0.00 & 0.02 & 0.01 & 3.0 \\
$\mathrm{Fe}(\mathrm{mg} / \mathrm{l})$ & 192 & 0.02 & 0.00 & 0.01 & 0.01 & 0.3 \\
$\mathrm{Na}(\mathrm{mg} / \mathrm{l})$ & 192 & 16.81 & 6.47 & 9.65 & 1.65 & 200 \\
$\mathrm{~K}(\mathrm{mg} / \mathrm{l})$ & 192 & 6.9 & 4.97 & 5.75 & 0.27 & - \\
$\mathrm{Ca}(\mathrm{mg} / \mathrm{l})$ & 192 & 27.01 & 1.99 & 11.5 & 1.89 & - \\
$\mathrm{Mg}(\mathrm{mg} / \mathrm{l})$ & 192 & 1.42 & 0.39 & 0.86 & 0.26 & 0.2 \\
\hline
\end{tabular}

Turb is the Turbidity; EC is the Electrical conductivity; Max is the Maximum; Min is the Minimum; Avg is the Average; SON is the Standard deviation 35 is the Standard Organisation of Nigeria; ${ }^{36} \mathrm{FEPA}$ is the Federal Environmental Protection Agency (1991) 


\section{RESULTS}

\subsection{General Water Characteristics}

Tables 1 and 2 showed the basic statistics of the physico-chemical and micro-biological properties of the baseline groundwater samples in the study area. Turbidity ranged from 0.00-0.06 with a mean of 0.03 . EC varies from $0.79-8.01 \mathrm{mscm}^{-1}$ with a mean of 4.15. The $\mathrm{pH}$ of the baseline water samples varies from 3.16-8.07, with a mean of 5.64 indicating that the water is acidic in nature compared to Ilaro wells in Ogun State which are more alkaline with $\mathrm{pH}$ range of 6.5-9.5 [37] and similar to Ibeno wells in Akwalbom State with an acidic $\mathrm{pH}$ range of 5.6-6.8 [38]. The most abundant cations with respect to average were $\mathrm{Ca}^{2+}$, $\mathrm{Na}^{+}$, and $\mathrm{K}^{+}$while $\mathrm{NO}_{3}^{-}, \mathrm{Cl}$, and $\mathrm{PO}_{4}^{2-}$ were the most abundant anions.

Table 2: Statistics of Microbiological analyses of the study area

\begin{tabular}{lcccccc}
\hline Parameters & $\begin{array}{c}\text { No. } \\
\text { of } \\
\text { Data }\end{array}$ & Max & Min & Avg & SD & SON $^{35}$ \\
\hline TCC (cfu/100ml) & 192 & 11.02 & 0.00 & 4.00 & 0.38 & 10 \\
$\begin{array}{l}\text { E-Coli Count } \\
\text { (ECC)(cfu/100ml) }\end{array}$ & 192 & 1311.10 & 886.98 & 1115 & 11.62 & - \\
$\begin{array}{l}\text { Yeast Count (YC) } \\
\text { (cfu/100ml) }\end{array}$ & 192 & 413.01 & 146.99 & 277 & 7.76 & - \\
Fungi (cfu/100ml) & 192 & 34.01 & 0.00 & 14.0 & 1.19 & - \\
\hline
\end{tabular}

Cadmium (Cd), Nickel ( $\mathrm{Ni}$ ) and Chromium (Cr) were either undetected in the water samples or were below detection limits. Calcium (Ca) concentration in the groundwater which ranged from $1.99-27.01 \mathrm{mg} / \mathrm{l}$ with mean average value of $11.5 \mathrm{mg} / \mathrm{l}$ was greater than the range of $2.5-12.9 \mathrm{mg} / \mathrm{l}$ and mean of $7.9 \mathrm{mg} / \mathrm{l}$ recorded for Ibeno wells by [38] and were within the WHO [39]permissible limit of $200 \mathrm{mg} / \mathrm{l}$. The chloride concentration which ranged from 4.48-46.85 mg/l with mean of $24.63 \mathrm{mg} / \mathrm{l}$ were less than the range of $97.5-215.9 \mathrm{mg} / \mathrm{l}$ with mean of $175.2 \mathrm{mg} / \mathrm{l}$ obtained for Ibeno wells by [38] and were within SON [35] limit of $250 \mathrm{mg} / \mathrm{l}$. TC in the study area varies from $0.00-11.01$ with a mean of $4 \mathrm{cfu} / 100 \mathrm{ml}$. EC varies from 886.98 $1311.1 \mathrm{cfu} / 100 \mathrm{ml}$ in the study area with a mean of concentration of $1114.75 \mathrm{cfu} / 100 \mathrm{ml}$. E-Coli is more predominant than yeast and fungi in the water samples in the study area. Mean yeast and fungi concentrations were 277.13 and $14.13 \mathrm{cfu} / 100 \mathrm{ml}$ and ranged from $154.99-429.01 \mathrm{cfu} / 100 \mathrm{ml}$ and $0.00-34.01$ $\mathrm{cfu} / 100 \mathrm{ml}$ respectively. Oke Onigbin had the highest E-Coli and Fungi concentrations of 1311.10 and 34.01 cfu/100ml respectively while Edidi had the highest yeast concentration of $429.01 \mathrm{cfu} / 100 \mathrm{ml}$.

The chemical composition of both WG and PP are shown in Table 3 with WG having a higher $\mathrm{pH}$ of 7.94 and PP with a $\mathrm{pH}$ of 5.93. Table 3 also showed that the main components in $\mathrm{WG}$ are $\mathrm{NaNO}_{2}, \mathrm{SO}_{4}$ and $\mathrm{Cl}_{2}$ while the major components in $\mathrm{PP}$ are $\mathrm{NaNO}_{2}, \mathrm{Ca}, \mathrm{CaCO}_{3}$, $\mathrm{SO}_{4}, \mathrm{Mg}$ and $\mathrm{ClO}_{2}$.

Table 3: Chemical composition of Water Guard and Pur Purifier

\begin{tabular}{|c|c|c|}
\hline Parameters & Water Guard & Pur Purifier \\
\hline $\mathrm{pH}$ & 7.94 & 5.93 \\
\hline Total Alkalinity $\left(\mathrm{CaCO}_{3}\right)(\mathrm{mg} / \mathrm{l})$ & ND & $135 \mathrm{mg} / \mathrm{l}$ \\
\hline $\mathrm{TH}\left(\mathrm{CaCO}_{3}\right)(\mathrm{mg} / \mathrm{l})$ & ND & $130 \mathrm{mg} / \mathrm{l}$ \\
\hline DO (mg/l) & 0.00 & 1.04 \\
\hline $\mathrm{Cl}_{2}(\mathrm{mg} / \mathrm{l})$ & 0.14 & 1.22 \\
\hline $\mathrm{NO}_{3}(\mathrm{mg} / \mathrm{l})$ & 0.00 & 1.26 \\
\hline $\mathrm{SO}_{4}(\mathrm{mg} / \mathrm{l})$ & 7 & 58 \\
\hline $\mathrm{PO}_{4}(\mathrm{mg} / \mathrm{l})$ & ND & 0.51 \\
\hline $\mathrm{Cr}(\mathrm{mg} / \mathrm{l})$ & ND & 0.26 \\
\hline $\mathrm{Ni}(\mathrm{mg} / \mathrm{l})$ & 0.10 & 2.75 \\
\hline $\mathrm{Zn}(\mathrm{mg} / \mathrm{l})$ & 0.07 & 2.59 \\
\hline $\mathrm{Fe}(\mathrm{mg} / \mathrm{l})$ & 0.01 & 2.85 \\
\hline $\mathrm{Na}(\mathrm{mg} / \mathrm{l})$ & 0.6 & 1.85 \\
\hline $\mathrm{K}(\mathrm{mg} / \mathrm{l})$ & 1.2 & 3.7 \\
\hline $\mathrm{Ca}(\mathrm{mg} / \mathrm{l})$ & ND & 219 \\
\hline $\operatorname{Mg}(\mathrm{mg} / \mathrm{l})$ & ND & 29 \\
\hline $\mathrm{Al}(\mathrm{mg} / \mathrm{l})$ & ND & 0.23 \\
\hline Total Bromine $\left(\mathrm{Br}_{2}\right)(\mathrm{mg} / \mathrm{l})$ & 0.09 & 3.10 \\
\hline Ammonia (mg/l) & 0.00 & 4.75 \\
\hline $\mathrm{Cu}(\mathrm{mg} / \mathrm{l})$ & 0.00 & 1.75 \\
\hline Nitrite $(\mathrm{mg} / \mathrm{l})\left(\mathrm{NaNO}_{2}\right)(\mathrm{mg} / \mathrm{l})$ & 15 & 460 \\
\hline Chlorine dioxide $\left(\mathrm{ClO}_{2}\right)(\mathrm{mg} / \mathrm{l})$ & 0.1 & 9.9 \\
\hline Ammonium $\left(\mathrm{NH}_{4}\right)(\mathrm{mg} / \mathrm{l})$ & ND & 0.31 \\
\hline
\end{tabular}

\subsection{Efficiency of Disinfection}

The efficiencies of the three disinfection methods are shown in Table 4. The disinfection efficiency is defined as a percentage change in concentration for the physico-chemical parameters and percentage change in count for the microbial parameters. Boiling and Water Guard (WG) achieved turbidity disinfection (or removal) efficiency of $93.3 \%$ which was higher than the $66.7 \%$ disinfection efficiency recorded by Pur Purifier (PP). In terms of EC, PP recorded the highest removal efficiency of $61.44 \%$ followed by WG with removal efficiency of $22.89 \%$ while concentration of EC increased with boiling. All the pre- and posttreated water were far below the $1000 \mathrm{~ms} / \mathrm{cm}$ 
prescribed by SON. In addition, all the pre- and posttreated water were found to have $\mathrm{pH}$ values below the SON recommended lower limit of 6.5, even though their $\mathrm{pH}$ increased. This showed that they are acidic and require alkaline treatment. PP recorded the highest $\mathrm{pH}$, followed by Pur of 5.97 and WG of 5.79.

Furthermore, PP recorded the highest TDS removal efficiency of $64.55 \%$ followed by boiling which recorded $52.73 \%$ and WG $40.91 \%$. Chloride ion was found to increase substantially for both PP and WG with an increase of 525\% and 520.83\% respectively. The increase can be attributed to their chloride contents which plays crucial role in disinfection. Likewise, PP recorded the highest $\mathrm{NO}_{3}$ removal efficiency of $92.3 \%$. In contrast, $\mathrm{NO}_{3}$ concentration increased for both boiling and WG. The pre- and posttreated water samples had chloride and $\mathrm{NO}_{3}$ concentrations which were below their recommended limits of $250 \mathrm{mg} / \mathrm{l}$ and $50 \mathrm{mg} / \mathrm{l}$ respectively. Considering $\mathrm{PO}_{4}$, WG had the highest disinfection efficiency of $18.1 \%$ followed by boiling of $13 \%$.

Table 4: Disinfection efficiency in terms of percentage removal/addition of parameters

\begin{tabular}{lccc}
\hline Parameters & Boiling & Water Guard & Pur Purifier \\
\hline Turbidity & -93.3 & -93.3 & 66.7 \\
$\mathrm{EC}$ & -21.19 & -61.44 & -22.89 \\
$\mathrm{Ph}$ & +22.12 & +7.96 & +13.27 \\
$\mathrm{TDS}$ & +52.73 & +40.91 & +64.55 \\
$\mathrm{Cl}$ & -83.6 & +520.8 & +525 \\
$\mathrm{NO}_{3}$ & +111.0 & +37.61 & -92.3 \\
$\mathrm{PO}_{4}$ & -13 & -18.1 & -7.81 \\
$\mathrm{Na}$ & +216.7 & +250 & $+1,133.3$ \\
$\mathrm{~K}$ & -10.4 & -14.8 & -13.9 \\
$\mathrm{Ca}$ & +81.82 & +81.82 & +172.73 \\
$\mathrm{Mg}$ & +9.47 & +8.07 & +11.93 \\
$\mathrm{TCC}$ & -65.5 & -75 & -96.9 \\
ECC & -99.7 & -99.9 & -99.6 \\
Yeast count & -35.9 & -93.5 & -98.9 \\
Fungi count & -77.6 & -87.5 & -78.6 \\
\hline
\end{tabular}

- = removal $+=$ increase

The average zinc contents of groundwater treated with boiling, WG and PP were $0.09 \mathrm{mg} / \mathrm{l}, 0.17 \mathrm{mg} / \mathrm{l}$ and $0.04 \mathrm{mg} / \mathrm{l}$ respectively, which were below the SON recommended limit of $3 \mathrm{mg} / \mathrm{l}$. All the three water treatments experienced increase in Na concentration. The increases were $1,333.3 \%, 250 \%$ and $216.7 \%$ for PP, WG and boiling respectively. In terms of Potassium (K) content, WG had the highest removal efficiency of $14.8 \%$, followed by PP of $13.9 \%$. Furthermore, the treated water experienced increase in $\mathrm{Ca}$ and $\mathrm{Mg}$ concentrations. PP recorded the highest Ca increase of
$172.73 \%$ while WG and boiling recorded the same increased concentration of $81.82 \%$. This is because PP contains Calcium hypochlorite $\left[\mathrm{Ca}(\mathrm{OCl})_{2}\right]$ Also, PP achieved the highest increase in $\mathrm{Mg}$ concentration of $11.93 \%$ followed by boiling with an increased concentration of $9.47 \%$. No prescribed limit was prescribed by SON for Ca but the Ca concentration of the pre- and post-treated water samples were below the WHO prescribed limit of $200 \mathrm{mg} / \mathrm{l}$. All the treated water samples experienced an increase in $\mathrm{Mg}$ concentration with PP recording the highest increase of $11.93 \%$. The pre- and post-treated water samples were above the SON prescribed limit of $0.2 \mathrm{mg} / \mathrm{l}$. The high $\mathrm{Mg}$ content could be attributable to the dissolution of $\mathrm{Mg}$ from the predominant clayey rock samples which characterize the geology of the area.

In terms of TCC, PP recorded the highest disinfection efficiency of $96.9 \%$ followed by WG and boiling with TCC disinfection efficiencies of $75 \%$ and $65.5 \%$ respectively. For ECC, WG recorded the highest disinfection efficiency of $99.9 \%$ followed by boiling and PP with disinfection efficiencies of $99.7 \%$ and 99.6\% respectively. In terms of YC, PP recorded the highest disinfection efficiency of $98.9 \%$ while WG and boiling achieved disinfection efficiencies of $93.5 \%$ and $35.9 \%$ respectively. On the other hand, for FC, WG recorded the highest disinfection efficiency of $87.5 \%$ followed by PP and boiling with disinfection efficiencies of $78.6 \%$ and $77.6 \%$ respectively.

\subsection{Comparative Cost Analyses}

While [40] recommended a minimum water requirement of 5 litres per capita per day for both drinking and cooking, [41] recommended 7.5 litres per capita per day. The 7.5 litres per capita per day was selected because it took care of the 4.5 litres per capita per day minimum drinking water requirement recommended by [42] and 3 litres per capita per day recommended by [43] required for cooking. Assuming a family size of six comprising father, mother, and four children, the total household water daily demand for both drinking and cooking is 45 litres. Also, assuming a 30-day month, the total minimum household water daily requirement for both drinking and cooking is 45 x $30=1,350$ litres. Since Pur Purifier pack treats 10 litres of water, this implies therefore that the total number of packs required per month is 135 packs. At \#30 per pack, the total expenditure per month equals $135 \mathrm{X} \mathrm{N25}=\mathrm{N} 3,375$. 
With respect to WG, 1 capful which is equivalent to 10 $\mathrm{ml}$ is required to disinfect 25 litres of water while two capfuls are required for very dirty water. Since the water in our study area is relatively clean and clear, 1 capful was used. The quantity of $\mathrm{ml}$ of WG required to treat 1350 litres is $540 \mathrm{ml}$, which is equivalent to 4 bottles of WG approximately. At $\mathrm{N} 60$ per bottle, the total expenditure per month on WG is $\$ 60 \times 4=\$ 240$. The electric stove used was Mikachi hot plate with model number MK 8010. The electric stove consumed $1000 \mathrm{~W}$ for rolling boiled 3.63 litres of water in 12 minutes. Therefore, the power consumed was 0.2 KWh. Since the cost of power supply in Landmark University is $\$ 1,000$ for $37.04 \mathrm{KWh}$, therefore, the cost of the power consumed was $\$ 5.40$. With monthly household consumption of 1350 litres for drinking and cooking, the total expenditure per month is N2,008.

This showed that the cheapest disinfection method is WG with a monthly household cost of $\$ 240$, followed by electric stove with a cost of $\$ 2,008$ while the most expensive of the three methods was PP with a total household cost of $\$ 3,375$.

\section{DISCUSSION}

The acidic $\mathrm{pH}$ of the groundwater in the study area indicates contamination from anthropogenic sources [37]. The apparent sources of contamination were poor sewerage and waste disposal, open defecation, poor sanitary and hygiene practices, leaching from the aquifer and droppings from domesticated animals. Since $\mathrm{pH}$ is found to affect enzymes and hormones in the body which control metabolism, growth and development [38], there is need for alkalinisation treatment of the groundwater in the study area. The apparent clarity of the groundwater samples with turbidity values ranging from 0.00 NTU-0.06 NTU which was below the SON prescribed limit of 5 NTU could create a misleading impression that the groundwater sources in the area is safe for drinking without disinfection. This was also the case with spring waters in Nsukka which were seen as clean and safe even though they were contaminated by Total coliform and E-coli [44]. The turbidity values were below the mean value of 4.1 NTU obtained for Kwara State by [45], 11.9 NTU and 21.9 NTU obtained by [46] for protected and open wells and 2.8 NTU-28.63 NTU obtained by [38] for Ibeno wells.

Furthermore, the TDS for the study area which ranged from $0.19 \mathrm{mg} / \mathrm{l}-2.53 \mathrm{mg} / \mathrm{l}$ were less than the range of
$4.83 \mathrm{mg} / \mathrm{l}-183.55 \mathrm{mg} / \mathrm{l}$ recorded for Ilaro groundwater by [37] and was less than the average of $553.7 \mathrm{mg} / \mathrm{l}$ obtained for Kwara State by [45]. Since the TDS were higher than TSS value in all the water samples, therefore, treatment methods should focus on removing the TDS than on suspended solids. High solid concentration in water is found to affect solubility of oxygen [38].

The increased values of DO in all the treated samples were similar to the report of [4] when water was treated with boiling and WG and could be traced to the reduction in the BOD [4]. The $\mathrm{BOD}_{5}$ values of the raw water samples which range from $2.5-3.6 \mathrm{mg} / \mathrm{l}$ were within the maximum value of $6.0 \mathrm{mg} / \mathrm{l}$ recommended by [47]. The TH which ranged from $91.99 \mathrm{mg} / \mathrm{l}$ $219.51 \mathrm{mg} / \mathrm{l}$ was greater than the TH range of 2.7 $\mathrm{mg} / \mathrm{l}-109.5 \mathrm{mg} / \mathrm{l}$ for Ibeno wells obtained by [38]. No limit was prescribed by SON for TH. In comparison with the WHO limit of $100 \mathrm{mg} / \mathrm{l}$, most of the wells were found to have $\mathrm{TH}$ which exceeded the limit.

In addition, though their $\mathrm{NO}_{3}$ values range from 3.18 $\mathrm{mg} / \mathrm{l}-192.25 \mathrm{mg} / \mathrm{l}$, most of the wells recorded high nitrate values which exceeded the SON limit of 50 $\mathrm{mg} / \mathrm{l}$, and this poses potential health risk to pregnant women and infants because it causes methaemoglobinemia at high concentrations [38]. Although there is no established limit for phosphate, high phosphate concentration is known to favour the growth of algae which could release cyanotoxins which is detrimental to health [38].

The $\mathrm{Pb}$ values for the study area which range from $0.02 \mathrm{mg} / \mathrm{l}-0.05 \mathrm{mg} / \mathrm{l}$ were similar to the range of $0.01 \mathrm{mg} / \mathrm{l}-0.019 \mathrm{mg} / \mathrm{l}$ obtained by [48] for shallow wells in Patigi but lower compared to the range of $7.53 \mathrm{mg} / \mathrm{l}-21.35 \mathrm{mg} / \mathrm{l}$ obtained for wells in Ibadan. None of the three disinfection methods was efficient in lead removal since the $\mathrm{Pb}$ concentration posttreatment ranged between $0.07 \mathrm{mg} / \mathrm{l}-0.36 \mathrm{mg} / \mathrm{l} . \mathrm{Pb}$ is carcinogenic and toxic to the central and peripheral nervous systems and retards mental development of infants [49].

Results shown in Table 4 showed that disinfection treatments applied to groundwater samples improved not only the microbiological properties of the treated water samples but also changed their physicochemical properties. While some parameters such as $\mathrm{pH}, \mathrm{TDS}, \mathrm{TH}, \mathrm{DO}, \mathrm{Na}, \mathrm{Ca}$ and $\mathrm{Mg}$ were found to experience increased concentration post-treatment, some were significantly removed by the three disinfection methods. 
In summary, in terms of disinfection efficiency, PP achieved the highest removal efficiency for EC (61.44\%), $\mathrm{NO}_{3}$ (92.3\%), TCC (96.9\%) and YC (98.9\%). On the other hand, WG recorded the highest removal efficiency for phosphate (18.1\%), K (14.8\%), ECC (99.9\%) and FC (87.5\%) while boiling achieved the highest removal efficiency for chlorine (83.6\%) and jointly recorded the highest turbidity removal efficiency of $93.3 \%$ alongside WG.

In terms of microbiological disinfection efficiency, the results showed that the E-coli were significantly removed by the three disinfection methods with high disinfection efficiency range of $99.6 \%-99.9 \%$. E. coli removal efficiency of $100 \%$ and $99.98 \%$ achieved by WG with WW and BW were comparable to the $100 \%$ removal efficiency reported by [26] with WG treated spring water. In addition, the $99.63 \%$ removal efficiency achieved with PP in both WW and BW was close to the $100 \%$ removal efficiency obtained by [50] and [51]. For boiling, the 99.22\% and 99.48\% disinfection efficiency achieved for E. coli in WW and BW were very close to the $100 \%$ removal efficiency of Faecal coliform reported by [52] after ten minutes of boiling and were higher than the 99 disinfection efficiency reported by [53]. Also, the 65.6\% - 96.57\% disinfection efficiency range recorded for TCC by the three disinfection methods was found to compare well with the $86.2 \%$ reduction achieved by [54] for shallow wells, borehole water and outdoor tap samples but were lower compared to the $86-99 \%$ reduction obtained by [55].

More than 95\% of the WS fell within the 'low-risk' category of not more than $10 \mathrm{TC} / 100 \mathrm{~mL}$ which indicated a lower contamination compared to the WS treated by [55] having about $60 \%$ and over $20 \%$ within the 'low-risk' and 'very-high risk' categories respectively.

Since cost is one of the limiting factors in the uptake of household disinfection methods as reported by [28], WG is recommended since it presents the cheapest treatment method compared to boiling and Pur purifier.

\section{CONCLUSION}

The groundwater resources in the study area were found to be contaminated and require disinfection to make them potable and safe for human consumption. The efficiencies of the three disinfection methods applied namely boiling, water guard and pur purifier varied in terms of removal of unwanted physico- chemical properties, anions, heavy metals and minerals and microbiological properties such as total coliform, E. coli, yeast and fungi. The choice of the disinfection method to apply to a particular water source depends on the key parameter(s) to be removed or enhanced. In summary, PP achieved the highest removal efficiency for $\mathrm{EC}, \mathrm{NO}_{3}$ total coliform and yeast while WG recorded the highest removal efficiency for phosphate, potassium, E. coli and Fungi while boiling achieved the highest removal efficiency for chlorine and jointly recorded the highest turbidity removal efficiency alongside WG.

It is recommended that further investigation should be done to optimize the efficiency of the three disinfection methods. Likewise, public enlightenment should be embarked upon by the State and Local Governments to sensitize the rural populace on the importance of disinfecting groundwater sources used for drinking and cooking purposes. Based on comparative cost analyses, water guard is recommended as the cheapest disinfection method for household water used for drinking and cooking. To encourage the uptake of WG by rural households, there is need for strategic marketing of the product especially in rural areas. The successful adoption of the product will help reduce the consumption of other unsafe drinking sources of water and will also help safeguard the health of the rural populace against preventable water-borne diseases.

\section{ACKNOWLEDGMENT}

The authors highly appreciate the support received from colleagues in the course of this research.

Conflict of interest: There is no conflict of interest.

\section{REFERENCES}

[1] Falbo,K., Schneider, R.L., Buckley, D.H., Walter, M.T., Bergholz, P.W., Buchanan, B.P. "Roadside ditches as conduits of fecal indicator organisms and sediment: Implications for water quality management", Journal of Environmental Management, 128, pp. 1050-1059, 2013.

[2] Baiga, J.A., Kazia, T.G., Araina, M.B., Afridi, H.I., Kandhro, G.A., Sarfraza, R.A., Jamal, M.K., Shah, A.Q. "Evaluation of arsenic and other physico-chemical parameters of surface and ground water of Jamshoro, Pakistan", Journal of Hazardous Materials, 166, pp. 662-669, 2009.

[3] Huber, M.K. "Bottled water: The risks to our health, our environment and our wallets", Thesis, School of Public and Environmental Affairs, 2010, Accessed November 20, 2014. 
[4] Sojobi, S.O., Owamah H.I., and Dahunsi, S.O. "Comparative study of household water treatment in a rural community in Kwara State, Nigeria", Nigerian Journal of Technology, 33 (1), pp. 134-140, 2014.

[5] Casanovas-Massana, A., Blanch, A. R. "Characterization of microbial populations associated with natural swimming pools", International Journal of Hygiene and Environmental Health, 216, pp. 132- 137, 2013.

[6] Ayandiran, T.A., Ayandele A.A., Dahunsi, S.O. and Ajala, 0. 0. "Microbial assessment and prevalence of antibiotic resistance in polluted Oluwa River, Nigeria", Egyptian Journal of Aquatic Research, 40, 291-299, 2014

[7] Dahunsi, S. O., Ayandiran, T. A., Oranusi, U.S. and Owamah, H. I. "Drinking water quality and public health of selected communities in South Western Nigeria", Water Quality, Exposure and Health, 6, pp. 143-153, 2014

[8] Azizullah A., Khattak, M.N.K., Richter P. and Hader D.P. "Water pollution in Pakistan and its impact on public health-A Review", Environment International, 37, pp. 479-497, 2011.

[9] WHO. "Guidelines for drinking water quality”, World Health Organization, Geneva, Switzerland, 2004

[10] Wilkes, G., Edge, T.A., Gannon, V.P.J., Jokinen, C., Lyautey, E., Neumann, N.F., Ruecker, N., Scott, A., Sunohara, M., Topp, E., Lapen, D.R. “Associations among pathogenic bacteria, parasites, and environmental and land use factors in multiple mixed-use watersheds", Water Research, 45, pp. 5807-5825, 2011.

[11] Liang, Z., He, Z., Zhou, X., Powell, C.A., Yang, Y., He, L.M., Stoffella, P.J. "Impact of mixed land-use practices on the microbial water quality in a subtropical coastal watershed", Science of the Total Environment, 449, pp. 426-433, 2013.

[12] Coleman, B.L., Louie, M., Salvadori, M.I., McEwen, S.A., Neumann, N., Sibley, K., Irwin, R.J., Jamieson, F.B., Daignault, D., Majury, A., Braithwaite, S., Crago, B., McGeer, A.J. "Contamination of Canadian private drinking water sources with antimicrobial resistant Escherichia coli", Water Research, 47, 3026-3036, 2013.

[13] Novotny, V. "Water-energy nexus: retrofitting urban areas to achieve zero pollution", Building Research and Information, 41, 589-604, 2013.

[14] Arvai, J. and Post, K. "Risk management in a developing country context: improving decisions about pont-of-use water treatment among the rural poor in Africa", Risk Analysis, 32 (1), 67-80, 2012.

[15] Khan, S., Shahnaz M, Jehai N., Rehman S., Shah, M.T., Din S. "Drinking water quality and human health risk in Charsadda district, Pakistan", Journal of Cleaner Production, 60, pp. 93-101, 2013.
[16] UNICEF and WHO. "Progress on drinking water and sanitation, 2012 update", Accessed January 5, 2015.

[17] Aish, A.M. "Drinking water quality assessment of the middle governorate in the gaza strip Palestine", Water Research and Industry, 4, pp. 13-20, 2013.

[18] Zhang J. "The impact of water quality on health: Evidence from the drinking water infrastructure program in rural China", Journal of Health Economics, 31, 122-134, 2012.

[19] Schmidt, W. and Cairncross, S. Household water treatment in poor populations: Is there enough evidence for scaling up now? Environment Science Technologies, 43.4, pp. 986-992, 2009.

[20] Mellor J.E., Smith J.A., Samie A. and Dillingham, R.A. "Coliform sources and mechanisms for regrowth in household drinking water in Limpopo, South Africa", Journal of Environmental Engineering, pp. 1152-1161, 2013.

[21] Do, A.T., Kuroda, K., Hayashi, T., Nga, T.T.V., Oguma, K. and Takizawa, S. "Household survey of installation and treatment efficiency of point-of-use water treatment systems in Hanoi, Vietnam", Journal of Water Supply: Research and TechnologyAQUA, 63 (2), 154-161, 2014.

[22] Roma, E., Bond, T., and Jeffrey, P. "Factors involved in sustained use of point-of-use water disinfection methods. A field study from Flores Island, Indonesia", Journal of Water and Health, 12 (3), pp. 573-583, 2014.

[23] Luoto, J., Najnin, N., Mahmud, M., Albert, J. aIslam, M.S. Luby S, Unicomb L and Levine D.I. "What pointof-use water treatment products do consumers use? Evidence from a randomized controlled trial among the urban poor in Bangladesh", Plos ONE, 6 (10), pp. 1-8, 2011.

[24] Rosa, G. and Clasen, T. "Estimating the scope of household water treatment in low-and middleincome countries", American Journal of Tropical Medicine and Hygiene, 82, pp. 289-300, 2010.

[25] Sodha S.V., Menon M., Trivedi K., Ati A., Figueroa E., Ainslie R., Wannemuehler K., Quick R. "Microbiologic effectiveness of boiling and safe storage in South Sulawesi, Indonesia" ,Journal of Water Health, 9 (3), 577-585, 2011.

[26] Ogunyoku, T.A., Nover, D.M., McKnzie, E.R., Joshi, G. and Fleenor, W.E. "Point-of-use drinking water treatment in the developing world: community acceptance, project monitoring and revision", International Journal for Service Learning in Engineering, 6 (1), pp. 14-32, 2011.

[27] UNICEF. "Promotion of household water treatment and safe storage in UNICEF WASH programmes", United Nations International Children Education Fund, 2008.

[28] PATH. "Market assessment of household water treatment products in eight African countries. 
Project Brief", 1-15, 2010, Accessed January 5, 2015.

[29] NBS 2011. Annual Abstract of Statistics, National Bureau of Statistics, Federal Republic of Nigeria, Accessed January 5, 2015.

[30] Aderibigbe, S. A., Awoyemi, A. O., Osagbemi, G. K. "Availability, Adequacy and Quality of Water Supply in Ilorin Metropolis, Nigeria", European Journal of Scientific Research, 23 (4), pp. 528-536, 2008.

[31] NBS 2010. Annual Abstract of Statistics, National Bureau of Statistics, Federal Republic of Nigeria, Accessed January 5, 2015.

[32] Olawuyi, J. F., Egbewale, B. E., Anifalaje, L. A. and Okochi, E. A. "Care seeking practices on diarrhea in a rural community in Nigeria", African Journal of Clinical and Experimental Microbiology, 5 (1), pp. 119-125, 2004.

[33] APHA. Standard methods for the examination of water and wastewater, Washington DC: American Public Health Association, 1992.

[34] APHA. Standard methods for examination of water and waste-water, Washington DC: American Public Health Association, 2012

[35] SON. "Nigerian Standard for Drinking Water Quality", Standards Organization of Nigeria, 2007

[36] FEPA 1991. "National Guidelines and Standards for water quality", Federal Environmental Protection Agency, Federal Ministry of Environment, 1991

[37] Adebisi, A.A., Omitogun, A.A., Koya, A. A. "Spatial scheme for groundwater flow and physical properties distribution in Ilaro, Southwestern Nigeria", Nigerian Journal of Technology, 33 (3), pp. 304-317, 2014

[38] Ukpong, A. C., Peter, B. U. "Physico-chemical and bacteriological analyses of drinking water in Ibeno Local Government Area of Akwa-Ibom State", Nigerian Journal of Technology, 31 (2), pp. 116-127, 2012.

[39] WHO. "Guidelines for Drinking water Quality: First Addendum to Third Edition", World Health Organization, Geneva, 2006.

[40] Martins, 0. "Water resources management and development in Nigeria-Issues and challenges in a new millennium", Inaugural lecture, University of Agriculture, Abeokuta, Ogun State, 2001.

[41] WHO. "Domestic water quantity, service level and health", World Health Organization, Geneva, Switzerland, 2003, Accessed June 28, 2015.

[42] WHO. "Water requirements, impinging factors, and recommended intakes", World Health Organization, Geneva, Switzerland, 2004, Accessed June 30, 2015.
[43] WHO. "Minimum water quantity needed for domestic uses", World Health Organization, Geneva, Switzerland, 2005, Accessed June 30, 2015.

[44] Okechukwu, M. E., Ogwo, V., Onuegbu, C. U., Mbajiorgu, C. C., Ezenne, G. I. "Water quality evaluation of spring waters in Nsukka, Nigeria", Nigerian Journal of Technology, 32 (2), pp. 233-240, 2013.

[45] Adeoye, P. A., Adeolu, A. R., Ibrahim, H. M. “Appraisal of Rural Water Supply: Case Study of Kwara State, North Central Nigeria", International Journal of Basic and Applied Science, 1(4), pp. 816-826, 2013.

[46] Lantagne, D. S. "Sodium hypochlorite for household and emergency water treatment", Journal of AWWA, pp. 106-119, 2008.

[47] Ademoroti, C.M.A. Environmental chemistry and toxicology. Ibadan: Foludex Press, 1996.

[48] Musa, J. J. and Ahanonu "Quality assessment of shallow groundwater in some selected agrarian communities in Patigi Local Government Area, Nigeria", International Journal of Basic and Applied Science, 1 (3), pp. 548-563, 2013.

[49] Wagboje, O. M., Ekundayo, O.T. "Assessment of heavy metals in surface water of the Ikpoba reservoir, Benin City, Nigeria", Nigerian Journal of Technology, 32 (1), pp. 61-66, 2013.

[50] Lantagne D. and Clasen T. "Point-of-use water treatment in emergency response", Waterlines, 31 (1-2), pp. 30-52, 2012.

[51] Johnston, R. "Preliminary Data: Response to Cyclone Sidr”, UNICEF, Dhaka, Bangladesh, 2008.

[52] Lehloesa, L. J. and Muyima, N. Y. O. "Evaluation of the impact of household treatment procedures on the quality of groundwater supplies in the rural community of the Victoria district, Easter Cape", Water SA, 26 (2), pp. 285-290, 2000.

[53] Clasen T., McLaughlin, C., Nayaar N., Boissonn S., Gupta R., Desai D., and Shah N. "Microbiological effectiveness and cost of disinfecting water by boiling in semi-urban india", American Journal of Tropical Medicine and Hygiene, 79 (3), pp. 407-413, 2008.

[54] Rosa G., Miller, M., Clasen T. "Microbiological effectiveness of disinfecting water by boiling in rural Guatemala", American Journal of Tropical Medicine and Hygiene, 82 (3), pp. 473-477, 2010.

[55] Psutka R., Peletz R., Michelo, S., Kelly P., Clasen. "Assessing the microbiological performance and potential cost of boiling drinking water in urban Zambia", Environmental Science Technology, 2011. http://researchonline.lshtm.ac.uk/577/dx.doc.org/ 10.1021/es2004045. Accessed January 5, 2015. 